\title{
MOLECULAR CHARACTERIZATION OF EQUINE HERPES VIRUS -1 (EHV-1) IN EGYPT
}

Noura.F. Alkhalefal, Ismail .I. Elkon ${ }^{2}$, Neven .A.Tolba ${ }^{1}$ and Effat .L. Elsayed ${ }^{3}$

${ }^{1}$ Department of Virology, Faculty of Veterinary Medicine, Kafrelsheikh University, 33516, Elgeish street, Kafrelsheikh, Egypt.

${ }^{2}$ Department of Gynecology \&Artificial Insemination, Faculty of Veterinary Medicine, Kafrelsheikh University, 33516, Elgeish Street, Kafrelsheikh, Egypt

${ }^{3}$ Rinder pest like disease department, Veterinary Serum \& Vaccine Research Institute -Abasia -Cairo.

Correspondence: Noura Alkhalefa .Veterinary Virology Department, Faculty of Veterinary Medicine, Kafrelshikh University, 33516, Elgeish street, Kafrelsheikh, Egypt, tel/fax: +2-047-323-1311; e-mail: nora_fysal2007@yahoo.com, noura_fysal@vet.kfs.edu.eg

\section{ABSTRACT}

Equine Herpes Virus -1 is one of the most viruses affecting equide family(Horse, Donkey \&Mule) causing severe economic losses to horse industry all over the world, due to respiratory manifestations, abortion of pregnant mares, and mayeloencephalopathy. Little reports have been made for investigation the prevalence and existence of equine herpes viruses (EHVs) in Egypt. In the present study, seventy clinical samples (6 placentas \& 64 nasal swabs) collected from different governorate in Egypt. Virus isolation by inoculating tissue suspensions into MDBK cells revealed characteristic CPE for EHV after the fourth passage within 7 days from inoculation in the form of aggregation of the cells together, rounding, and finally cell detachment. Serological confirmation of the isolated sample by FAT revealed intracytoplasmic greenish yellow fluorescence. DNA extraction and PCR of suspected samples existed Successful amplification of 700 bp of ULA5 gene of EHV-1 in 8 out of 70 examined samples.

Key words: Equine, Egypt, EHV-1, Virus isolation, FAT and PCR. 


\section{INTRODUCTION}

Equine herpes viruses (EHVs) are significant causes lead to of sever illness and mortality in domestic horse population worldwide (Slater et al., 2006). Among the five recognized EHVs, EHV-1is enveloped with double stranded DNA genome, the genome was composed of a unique long (UL) region and a unique short (US) region, which was flanked by two inverted repeat regions (IR and TR) and encodes at least 72 unique genes and 4 diploid genes (Telford et al., 1992). Classified under family herpesviridea, subfamily alphaherpesvirinae, genus Varicellovirus (Slater, 2007).

EHV-1 was first isolated from aborted mare in Argentine in Lexington in 1932 and $80 \%$ of horses had latent infection in the trigeminal ganglion and lymphocytes (Patel and Heldens., 2005). The involvement of lymphocytes results in development of a cell associated viraemia (Harless, 2006), which is responsible for the rapid dissemination of virus in secondary replication sites, including the gravid uterus spinal cord, testes and accessory sex glands without detectable effects on the fertility of stallions (Hebia et al.,2009).

Equine herpesviruses of type 1 and type 4 which are closely related antigenically and genetically, induce rhinopneumonitis and make longlive latent infections in the recovered horses in response to natural stresses as transportation, weaning and immune deficiency (Anonymous, 2008; Bresgen et al., 2012). The high prevalence is among young horses from weaning to 3 years of age (Walter, 2013). 
EHV-1 is the main cause of abortions, paresis and neonatal foal deaths, due to necrotizing vasculitis and thrombosis resulting from infection of endothelial cells lining the blood capillaries. In these lesions, the initiation of infection is likely to be by reactivated EHV-1 from latently infected leukocytes. However, host factors responsible for reactivation remain poorly understood .Elderly horses, mares and febrile horses are at higher risk for developing severe neurological illness (Patel and Heldens., 2005).

EHV-1 induced neurological pathology is mainly restricted to the vascular epithelium of arteries supplying the central nervous system, although the trigeminal ganglion is also involved and the resulting inflammatory response leads to myeloencephalitis. (Goehring et al., 2006).

EHV-1 and EHV-4 are considered the most important pathogens both clinically and economically. Both viruses are primarily belonged to respiratory tract infections of varying degrees, and make long-live latent infections in the recovered horses. However, EHV-1 may progress to induce more serious symptoms in the form of abortion, still birth and neurological disorders (Allen and Bryans, 1986; Studdert et al., 2003).

Different methods have been used for EHV infections diagnosis in clinical samples $(\boldsymbol{O I E}, 2008)$. The virus isolation in cell culture derived from equine- has been the standard diagnostic approach. Apart from glycoproteins critical for virus egress to host cells, encodes several membrane proteins. Among them, UL45 is a class II protein dispensable for growth in vitro but was recently determined as an important virulence factor of HSV-1 neurotropism (Lucjan et al., 2008). 
Further identification of the positive isolates was achieved by immunofluorescence, ELISA or immunoperoxidase using type-specific monoclonal antibodies (Borchers et al., 1997). During the last decades, several PCR assays were developed for identification and typing EHVs (Dynon et al., 2001; Galosi et al., 2001; Varrasso et al., 2001; Szeredi et al., 2003; Diallo et al., 2006; Elia et al., 2006). The results of such assays well correlated with virus isolation in terms of accuracy and sensitivity, but surpassed it in simplicity, rapidity, time saving and the independence on the presence of infectious virus in the clinical sample (Varrasso et al., 2001).

\section{MATERIAL AND METHODS}

\section{Sampling:}

Table (1): Definition of samples used in the study.

\begin{tabular}{|c|c|c|c|}
\hline $\begin{array}{c}\text { Disease } \\
\text { manifestation }\end{array}$ & Sample collected & Animal age & $\begin{array}{c}\text { Number of } \\
\text { samples }\end{array}$ \\
\hline $\begin{array}{l}\text { Respiratory } \\
\text { symptoms }\end{array}$ & Nasal swabs & $\begin{array}{l}\text { - Mature horses over 2 years } \\
\text { - Foals (6-18 months) }\end{array}$ & 64 \\
\hline Abortion & Placenta & Pregnant mares & 6 \\
\hline
\end{tabular}

Seventy samples were randomly collected from Gharbia and Kafr El Shekh Governorate, 20 out of them were apparently healthy and 50 were from the diseased horses and foals. The collected samples included swabs from different orifices in the body (nasal, pharyngeal and vaginal) in addition to tissue samples (placenta ) from aborted mares(table1). The specimens were grinded in phosphate buffered saline, $\mathrm{pH} 7.2$, containing antibiotics of streptomycin, $(50 \mathrm{mg} / \mathrm{ml}),(2000 \mathrm{U} / \mathrm{ml})$ penicillin, and $(2$ $\mathrm{mg} / \mathrm{ml}$ ) gentamycin. After freezing and thawing, the samples were clarified by centrifugation at $6000 \mathrm{rpm}$ for $10 \mathrm{~min}$; the collected supernatants were stored at $-70{ }^{\circ} \mathrm{C}$ until used. 


\section{Virus isolation:}

Isolation procedures were done according to OIE guidelines (OIE Terrestrial Manual 2013) Briefly, Use a T-75 flask of MDBK monolayer cells. The cells were grow under the standard culture conditions $\left(37^{\circ} \mathrm{C}, 5 \% \quad \mathrm{Co} 2\right.$ and $85 \%$ humidity) using an initial concentration $1.5 \times 105$ cells $/ \mathrm{ml}$.At $85 \%$ of cell confluence monolayer, tissue culture flasks are inoculated with $0.2 \mathrm{ml}$ of the Prepared Samples.the monolayers are rinsed twice with phosphate buffered saline (PBS) After addition of 5 $\mathrm{ml}$ of supplemented maintenance medium (MEM containing 2\% New born calf serum, the flasks are incubated at $37^{\circ} \mathrm{C}$ with daily inspection by microscopy for the appearance of characteristic EHV CPE then 3 cycles of Freezing and Thawing for Harvesting Supernatant is collected, stored in small aliquots at -80 .

\section{DNA extraction:}

Viral DNA was extracted from different collected samples. Extraction was carried out according to the instruction of the DNA extraction kits QIA amp Viral DNA mini kits (Qiagen, USA). Briefly, about $130 \mu \mathrm{l}$ from the samples was transferred to $570 \mu \mathrm{l}$ of the Qiagen lysis buffer. Positive control extraction from Ab4p virus (Abortgenic strain of EHV-1) was kindly provided by Dr. A. J. Davison, Glasgow University- Scotland, the virus had a titer of 4x105PFU/ml, will run in parallel to each sample. DNAs were resuspended and stored at -70 ${ }^{\circ} \mathrm{C}$ till use.

\section{Polymerase Chain Reaction (PCR):}

The DNA was further used for the amplification of full sequence of UL45 gene of EHV through gene specific forward 5'- (CTTGGA ATT CAT GGC AGG AGA CCC AAC A) -3' and reverse primer 5'- 
(TTT GCG GCC GCT TAC CGG GGA AAC GGT ATG A) -3'. the reaction mixture consisted of $5 \mu 1$ of extracted template DNA, $4.5 \mu \mathrm{DD}$ water, $1 \mu \mathrm{l}$ of forward primer and $1 \mu \mathrm{l}$ of reverse primer, $12.5 \mu \mathrm{l}$ of PCR master mix. PCR thermo cycling using (T3 Biometra-Germany).The PCR programing was: initial denaturation at $94^{\circ} \mathrm{C}$ for $5 \mathrm{~min}$, followed by 5 cycles consists of 3 temp $\left(98^{\circ} \mathrm{C}\right.$ for $10 \mathrm{sec}$., annealing at $48^{\circ} \mathrm{C}$ for 30 sec and extension at $72^{\circ} \mathrm{C}$ for $30 \mathrm{sec}$., 30 cycles of $98^{\circ} \mathrm{C}$ for $10 \mathrm{sec}$., $58^{\circ} \mathrm{C}$ for $30 \mathrm{sec}$., $72^{\circ} \mathrm{C}$ for $2 \mathrm{~min}$, followed by 1 cycle at $4^{\circ} \mathrm{C}$ for $\infty$. The PCR products were analyzed by electrophoresis on a $1.5 \%$ agarose gel containing ethidium bromide $0.5 \mu \mathrm{g} / \mathrm{ml}$

\section{Immune Fluorescence Antibody Assay (IFA):}

Immune Fluorescence Antibody Assay was performed according to Armin et al., (2004), briefly RK13 cells $40-50 \%$ monolayer were infected with EHV-1 Ab4p virus at (MOI=4) in 24 well plate at specific time point (overnight). The cells then fixed with $250 \mu$ of ice cold $4 \%$ paraformaldehyde at RT for 15 min on bio shaker, after discarding of the paraformaldehyde, the cell were washed 3 times with 1X PBS. Adding $250 \mu \mathrm{l}$ of $50 \mathrm{mM}$ NH4CL for each well and incubate at RT for $10 \mathrm{~min}$ on bio shaker, discard the NH4CL and add $240 \mu \mathrm{l}$ of $0.2 \%$ triton $100 \mathrm{x}$ for $10 \mathrm{~min}$ at RT on bio- shaker. Then the cells were blocked by $250 \mu \mathrm{l}$ of $3 \% \mathrm{BSA} / \mathrm{PBST}$ for $30 \mathrm{~min}$ at RT. The cells running with 3 rounds of washing then incubated with 1st antibody (purified poly clonal antibodies prepared against UL45 gene which diluted 1/500 in $0.005 \%$ PBST for $1 \mathrm{~h}$ at $37^{\circ} \mathrm{c}$ in co2 incubator, washed three times by $0.005 \%$ PBST. The cells then incubated with the $2^{\text {nd }}$ antibody FITC conjugated goat anti guinea pig IgG (sigma Aldrich, USA) diluted 1/200 in PBST for $1 \mathrm{~h}$ in $37^{\circ} \mathrm{C}$ incubator, after discarding the $2^{\text {nd }}$ antibody, the cell were washed with $0.005 \%$ PBST, and the slides were analyzed by fluorescence microscopy (Axiovert/Zeiss). 


\section{RESULT}
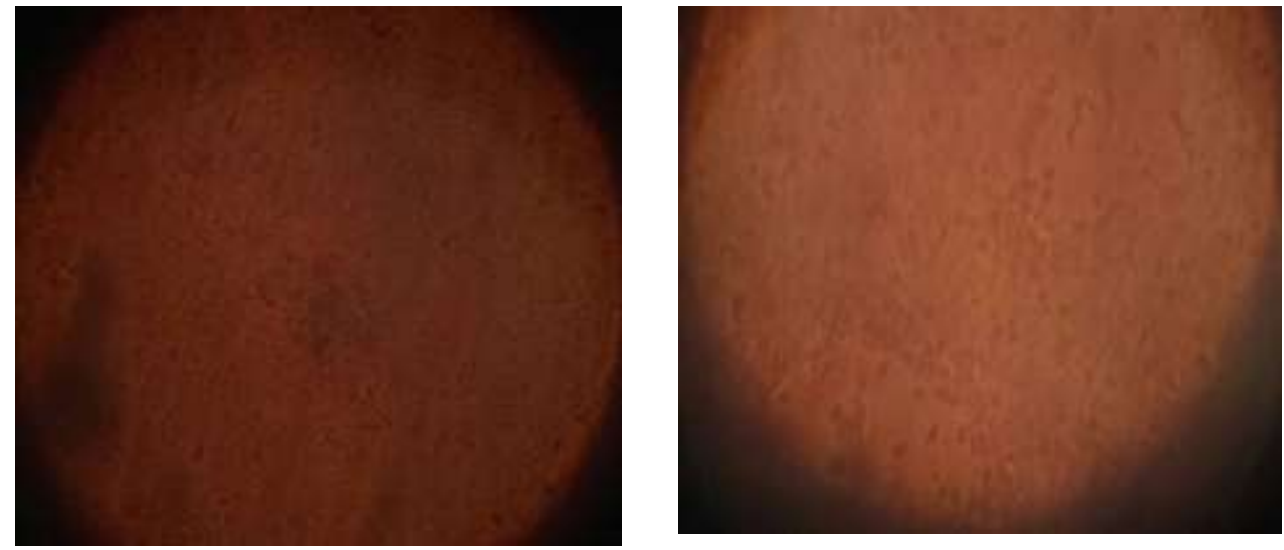

Fig (1): Non inoculated MDBK monolayer cell culture as cellular control

Fig (2): MDBK cells inoculated with sample suspension showing cell rounding and detachment
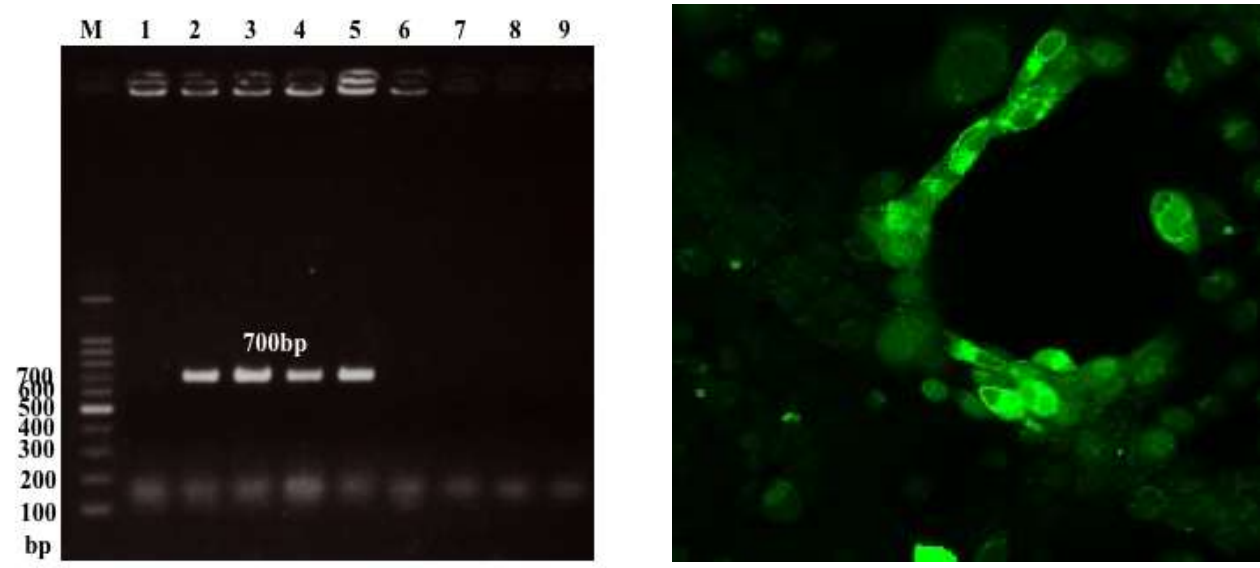

Fig (3): Gel electrophoresis for PCR Fig. (4): Fluorescence granules were products of the examined samples. Lanes;3-9 refer to the samples. Lane 1: Negative control, Lane 2: Positive control, M; 100 bp molecular weight DNA ladder. observed after 24 hours post inoculated RK13 cells of the $3^{\text {rd }}$ passage of inoculated samples using anti EHV1UL45 conjugated with FITC

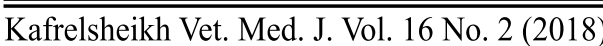




\section{DISCUSSION}

Worldwide, equine herpes viruses have a great economic and welfare impact on all horse sectors industry. They had several forms of the disease; including abortion, respiratory symptoms, and myeloencephalitis, that greatly affect the breeding and the performance ability of horses (Slater, 2007). In Egypt, there is a little information about epidemiology of EHVs regarding the prevalence, circulating strains and factors predisposing the infection

The presence of EHV was suspected from the epidemiological features of the collected samples. The study was continued for 2 years (2015 to 2016) using samples from all suspected cases either those showing sneezing, nasal discharge, coughing and/or abortion . Samples were inoculated in tissue culture cells (MDBK cells) which showed specific CPE in the form of rounding and cellular detachment after seven days of the $3^{\text {rd }}$ cell passage. This may have been a consequence of the low virus titre in the inoculated samples. Later the virus became adapted to MDBK cells .Scott et al (1983) considered that EHV-1 exists in the infected mononuclear cells in non infective or subvirion forms. The obtained results were in agreement with Warda et al (2003) how succeeded in isolation of EHV-1 on BHK cells

As a rapid monitoring of the EHV-positive samples, PCR was performed using specific primer sites against EHV-1UL45 gene, with an overall ratio of $11.4 \%$. such assay achieve the advantages of specific and rapid identification of the viral antigen. Moreover, economically it provided a highly sensitive diagnosis tool of different EHV infection in a 
large number of samples., the prevalence rate of the identified EHV-1 which determined in this report appeared to be lower than that recorded in other countries (Reubel et al., 1995; Nordengrahn et al., 2002). But in consistence with Haitham et al., (2011) who screening 93 clinical samples from Arabian horses for the presence of EHV antigens by semi-nested PCR assays and identified EHV-1, EHV-2, and EHV-4, with prevalence ratio $3.2 \%, 18.2 \%$, and $7.5 \%$ respectively.

Immunological techniques (IF) using specific EHV-1 antisera showed fluorescence granules confirmed that the isolated virus was EHV-1. Isolation of the virus from nasal swabs and the time at which CPE was observed, suggest that the isolated virus is EHV-1 rather than EHV-4. Abdel Hafez et al., (2010) confirmed EHV-1 infection from fetal fluid obtained from aborted mares at $7^{\text {th }}$ month of gestation using FAT.

The obvious role of EHV-1 in equine abortion is well documented throughout the world (van Maanen. 2002; Smith et al., 2003), although this virus strain was not recorded in any of the aborted samples which collected in this study.

\section{REFERENCES}

- Abdel-Hafez, Y.G .M., Abu maaty, A. M., Darwish , S.,(2010). Isolation of Equine Herpesvirus 1 (EHV-1)as a cause of reproductive disorders with emphasis on antigenic and genetic identification .International Journal of Microbiology 1(1):26-32.

- Allen GP, Bryans JT (1986). Molecular epizootiology, pathogenesis and prophylaxis of equine herpesvirus 1 infections. Progr. Vet. Microbiol. Immunol., 2: 78-144. 
- Anonymous, (2008). OIE Terrestrial Manual. Chapter 2.5.9. Equine rhinopneumonitis. pp. 894-903.

- Armin, B., Christoph, B., Hideki, I., Marvin, S., Leigh, Z., Klaus, F., John, H., William, R., and Ann, A., (2004). The Immediate-Early 63 protein of Varicella-Zoster virus: Analysis of functional domains required for replication in vitro and for T-cell and skin tropism in the SCID Model in vivo.Journal of Virology.

- Borchers K, Wollinger U, Goltz M, Broll H, Ludwig H (1997). Distribution and prevalence of equine herpesvirus type 2 (EHV-2) infections. Arch. Virol., 142: 917-928.

- Bresgen, C., M. Lämmer, B. Wagner, N. Osterrieder \& A. M. Damiani, (2012). Serological responses and clinical outcome after vaccination of mares and foals with equine herpesvirus type 1 and 4 (EHV-1 and EHV- 4). Veterinary Microbiology, 160, 9-16.

- Diallo IS, Hewitson G, Wright L, Rodwell BJ, Corney B (2006). Detection of equine herpesvirus type 1 using a real-time polymerase chain reaction. J. Virol. Methods 131: 92-98.

- Dynon K, Varrasso A, Ficorilli N, Holloway S, Reubel G, Li F, Hartley C, Studdert MJ, Drummer H (2001). Identification of EHV-3 (equine coital exanthema virus), equine gamma herpesviruses $2 \& 5$, Equine adenoviruses $1 \& 2$, equine arthritis virus and equine rhinitis $\mathrm{A}$ virus by polymerase chain reaction. Aust. Vet. J., 79: 695-708.

- Elia G, Decaro N, Martella V, Campolo M, Desario C, Lorusso E, Cirone F, Buonavoglia $C$ (2006). Detection of equine herpesvirus type 1 by real time PCR. J. Virol. Methods 133: 70-75. 
- Galosi CM, Vila Roza MV, Oliva GA, Pecoraro MR, Echeverria MG, Corva S, Etcheverrigaray ME (2001). A polymerase chain reaction for detection of equine herpesvirus- 1 in routine diagnostic submissions of tissues from aborted foetuses. J. Vet. Med. B Infect. Dis. Vet. Public Health 48: 341-346.

- Goehring, L. S., S. C.van Winden, C. van Maanen \& S. van Oldruitenborgh-Oosterbaan, (2006). Equine herpesvirus type 1assocated myeloencephalopathy in the Netherlands: A four-year retrospective study (1999-2003). Journal of Veterinary Internal Medicine, 20, 601-607.

- Harless, W. and N. Pusterla, (2006). Equine herpesvirus 1 and 4 respiratory disease in the horse. Clinical Techniques in Equine Practice, 5: 197-202.

- Hebia-Fellah, 1., A Le'aute', F. Fie'ni, S. Zientara, B.M. ImbertMarcille, B. Besse, G. Fortier, S. Pronost, F. Miszczak, B. Ferry, C. Thorin, J.L. Pellerin and J.F. ois Bruyas, (2009). Evaluation of the presence of equine viral herpesvirus 1 (EHV-1) and equine viral herpesvirus 4 (EHV-4) DNA in stallion semen using polymerase chain reaction (PCR). Theriogenology, 71: 1381-1389.

- Haitham, M., Asmaa, K., Ibrahim, M., Ahmed, A., and Mohamed, A., (2011). Prevalence of equine herpes viruses 1, 2 and 4 in Arabian horse population in Egypt. African Journal of Microbiology Research. Vol. 5 (27), pp. 4805-4811.

- Lucjan, S., Krzysztof, G., and Leszek, R., (2008): HSV-1 UL45 encodes a carbohydrate binding C-type lectin protein. Cell Cycle 7:2, pp. 269-271. 
- Nordengrahn A, Merza M, Ros C, Lindholmc A, Palfl V, Hannant D, Belak $S$ (2002). Prevalence of equine herpesvirus types 2 and 5 in horse populations by using type-specific PCR assays. Vet. Res., 33: 251-259.

- Office International Des Epizooties (OIE) (2008). Manual of Diagnostic Tests and Vaccines for Terrestrial Animals (Mammals, Birds and Bees). $6^{\text {th }}$ Edn. Editions of the OIE Biological Standards Commission, Paris, France.

- Patel J. R., Heldens. J. (2005). Equine herpesviruses 1 (EHV-1) and 4 (EHV-4) - epidemiology, disease and immunoprophylaxis: A brief review. The Veterinary Journal Volume 170, Issue 1, July 2005, Pages 14-23.

- Reubel GH, Crabb BS, Studdert MJ (1995). Diagnosis of equine gammaherpesvirus 2 and 5 infections by polymerase chain reaction. Arch. Virol., 140:1049-1060.

- Scott J. C., Dutta S. K., Myrup A. C. (1983). In vivo harboring of equine herpesvirus $\mathbf{1}$ in leukocyte populations and subpopulations and their quantitation from experimentally infected ponies. Am. J. vet. Res., 44, 1344-1348.

- Slater JD (2007). Equine herpesvirus in Equine infectious disease Section II. Saunders-Elsevier publisher, Philadelphia, pp. 134-153.

- Slater JD, Lunn DP, Horohov DW, Antezak DF, Babiuk L (2006). Report of the equine herpesvirus -1 Havermeyer Workshop, San Gimiganano, Tuscany. Vet. Immunol. Immunopath., 111: 3 -13. 
- Smith KC, Blunden AS, Whitwell KE, Dunn KA, Wales AD (2003). A survey of equine abortion, stillbirth and neonatal death in the UK from 1988 to 1997. Equine Vet. J., 35: 496-501.

- Studdert MJ, Hartley CA, Dynon K, Sandy JR, Slocombe RF, Charles JA, Milne ME, Clarke AF, El-Hage C (2003). Outbreak of equine herpesvirus type 1 myeloencephalitis: new insights from virus identification by PCR and the application of an EHV-1-specific antibody detection ELISA. Vet. Record 153: 417-423

- Szeredi L, Palfi V, Molnar T (2003). Comparison of methods for the diagnosis of equine herpesvirus type 1 infection. Acta Vet. Hung., 51: 153-163.

- Telford, E., Watson, M., McBride, K., and Davison, A., (1992). The DNA sequence of equine herpesvirus-1. Virology .189, pp.304-16.

- Van Maanen $C$ (2002). Equine herpesvirus 1 and 4 infections: an update. Vet. Q., 24: 58-78.

- Varrasso A, Dynon K, Ficorilli N, Hartley CA, Studdert MJ, Drumer $\boldsymbol{H E}$ (2001). Diagnosis of equine herpesvirus 1 and 4 by polymerase chain reaction. Aust. Vet. J., 79: 563-569.

- Walter, J., C. Seeh, K. Fey, U. Bleul \& N. Osterrieder, (2013). Clinical observations and management of a severe equine herpesvirus type 1 outbreak with abortion and encephalomyelitis. Acta Veterinaria Scandinavica, 55, 19-27.

- Warda SM (2003). Studies on equine viral abortion problem in Egypt. Ph.D. dissertation, Zagazig University (Benha Branch) Egypt. 